SSHRC Research Network on the Changing Nature of Work and Lifelong Learning

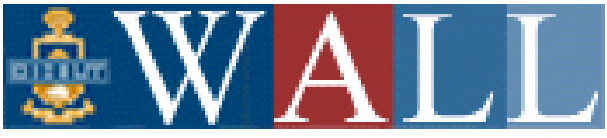

Working Paper No. 3, 2003

Hidden Dimensions of Work and Learning: The Significance of Unpaid Work and Informal Learning in Global Capitalism

By David W. Livingstone

Centre for the Study of Education and Work

Department of Sociology and Equity Studies in Education

Ontario Institute for Studies in Education of the University of Toronto 252 Bloor St. West, Toronto, ON, M5S 1 V6 


\title{
Hidden Dimensions of Work and Learning: The Significance of Unpaid Work and Informal Learning in Global Capitalism*
}

\author{
David W. LIVINGSTONE, Head \\ Centre for the Study of Education and Work \\ OISE/University of Toronto, Canada
}

\begin{abstract}
Over the past two centuries capitalist social relations and their underlying dynamics have become increasingly pervasive in the spaces of human life, and in particular in the relationships between employment and organized forms of education. The massive scope of this commodification has tended to obscure the enduring significance of other aspects of social practice, especially unpaid work and informal learning and their interrelations with education, employment and each other. These hidden dimensions continue to constitute large parts of our social lives and represent very substantial resources for progressive change in established forms of paid work and formal education. This paper develops this argument and provides some supportive evidence from a Canadian national survey on learning and work (see www. nall.ca) .
\end{abstract}

Keywords: Capitalism, Commodification, Unpaid Work, Informal Learning, Underemployment, Economic Alternatives.

\section{INTRODUCTION}

The defining feature of the capitalist epoch is the continual commodification of our lives. Our human labour powers, our means of production and consumption, even the water we drink and the air we breath are converted into commodities to be bought and sold in pursuit of monetary profit. But the conversion of our labours and means of production into commodities is far from universal. Judging from earlier human history, this conversion is likely to remain incomplete until a new epoch of production emerges from within global capitalism. All class-based modes of production have developed by taking over previously dominant modes of production as they find them rather than springing forth full blown. Both ancient slavery and medieval tribute-paying modes grew out of smaller subsistance-based communities. Industrial capitalism emerged through trading city enclaves within Western European feudalism.

The dominant form of labour in epochs of production-slavery in the slave mode, serfdom in feudalism and wage labour in capitalism - has never become the exclusive form of labour but always combined with other forms. At its height, European feudalism was sustained not only by serfdom but by independent small producers and growing numbers of hired wage labourers. Today, hired wage labour is most common but independent small commodity producers and even pockets of serfdom and slavery still persist, along with other emergent de-commodified forms of labour to be discussed below.

\footnotetext{
* Keynote Address, $3^{\text {rd }}$ International Conference on Work and Learning, University of Tampere, Finland, July 25-27, 2003. Published in Journal of Workplace Learning, 15(7/8), 359-367.
} 
Industrial capitalism is a few hundred years old, not very old in epoch of production terms. Many ideologues and scholars have prematurely predicted the demise of capitalism through the sheer weight of its internal contradictions, particularly the socialization of the forces of production (knowledge and technology enabling sufficient goods and services to meet basic needs universally with decreasing labour) versus private ownership of the means of production (competitive profit maximization by major shareholders and relative impoverishment for the rest of the world). But global capitalism may well be reaching its zenith with goods circulating world-wide and financial markets now operating on a 24/7 schedule. Many people are becoming increasingly sensitive to limits of commodification as it incurs sphere of life that those in the advanced capitalist world had previously seen as immune-like drinking water and breathing, as well as the more intimate spheres of our private lives.

It is certainly possible that further spatial extension of capitalist production enterprises around the world, along with the creation of new needs and associated new commodities will continue to fuel continuing capitalist expansion for some time. Consider China and Eastern Europe. Consider VCRs and personal computers.

Consider also the-re-privatization of previously state-appropriated services such as public power utilities. Pools of financial capital in the early part of the $20^{\text {th }}$ century were not large enough or their owners confident enough of sufficient profit vis a vis potential state regulation or appropriation as "essential services" to invest in full development of power grids in most advanced capitalist states. Hence, these capital infrastructures were often developed with public tax funds. Now that large-scale infrastructures have been built, many of these public utilities and their guaranteed customers are extremely attractive to much larger pools of private capital keenly seeking to continue to ensure competitive shareholder returns on investment. Socialized health care came later and more unevenly but has also been prone to similar re-privatization initatives recently.

All of these commodification tendencies are primarily indicative of private capital frenetically searching for expanded spheres of production to secure continuing profitability. The innermost dynamic of the capitalist mode of production remains appropriation of unpaid labour time, and ultimately profits, from direct producers -who are mainly interested in sustaining themselves and their families-- by owners of larger and larger private enterprises - increasingly aided by a growing coterie of well-paid managerial controllers of these productive labourers. The question of which side you are on in this class struggle has become more complex, with various intermediate and marginalized class locations, but it is still central to explaining economic change in our times. The use of more capital-intensive machinery in established spheres of production generally diminishes prospects for appropriating unpaid labour time; hence, all other things being equal, we have a falling rate of profit in established spheres. The bottom line is that persistent declining profits threaten the sustainability of the mode of production and additional spheres, especially new labour-intensive ones, must continually be found in order to sustain "shareholder capitalism". 


\section{EMERGENT FORMS OF LABOUR}

As the socialization and re-privatization of power utilities and health care programs suggest, commodification is a reversible process. But consider also the converse example of the public library. The private fee-based libraries of the $19^{\text {th }}$ century became mainly public in the $20^{\text {th }}$ century and now represent one of the leading cases of decommodification. Public libraries buy books and then allow all of us to borrow and use them serially without charge. Librarians are paid a wage or salary but they offer services based on use value rather than exchange value to garner profits. Public libraries were won through popular struggles. This is a clear case of socialization of the forces of intellectual production. Many other reversals of commodification are observable within capitalist societies

The classic argument for transition from the capitalist mode of production to a more egalitarian one is based on a key assumption about this continuing socialization of the forces of production. The massive dissemination of scientific and technological knowledge via public schooling, public libraries and public media, now complemented by the Internet, is presumed to be creating an ever-expanding public sphere of widely accessible production knowledge. The knowledge and information that is available to workers through this public sphere is seen as so contrary to the concentrated capitalist ownership of productive enterprises and centralized control over labour processes within them that the popular demand for more democratic production units and forms of labour will become undeniable. Increasing unemployment, job stress and other signs of job alienation have long been seen and frequently heralded by socialist revolutionaries as the harbingers of transformation to some version of economic democracy as a new mode of production.

Less optimistic social democrats advocate "stakeholder capitalism" while management gurus speak glowingly of the new era of the "learning organization". But what is clear from all these standpoints is that capital intensification in extractive and manufacturing industries has put an increasing premium on human mediation of expensive machinery over the last century. The rise of the service sector has been contingent on the selling of labour-intensive services rather than material goods. The proliferation of information technologies has made a wider array of work tasks dependent on worker self-monitoring. In short, there has been a secular trend for the motives and learning capacities of the workforce to play a more strategic role in the capitalist labour process. The dominant discourse of management theory has shifted from advocacy of scientific management of workers' bodily movements through extrinsic rewards to this current promotion of learning organizations designed to enable continuing learning and enhance worker motivation to share their knowledge. While actual working conditions in most paid workplaces may diverge from idealized versions of such learning organizations, there is little doubt that employers, employees and researchers alike have joined socialist revolutionaries in paying concerted attention to workers' knowledge. Whether democratization of capitalist workplaces will lead to reform or transformation of the mode of production remains an open question for the moment. What is fairly clear is that 
initiatives under various labels to allow or encourage workers in these enterprises to more fully and effectively utilize their increasing array knowledge and skills will continue for the foreseeable future.

As noted above, pre-capitalist forms of productive labour persist alongside hired wage labour within current capitalist production systems. But there are also other emergent forms of labour associated with community economic development efforts not driven by profit maximization. Co-operatives and other communitarian production units have worker-ownership and self-management of the labour process and are often centred on sustainability objectives rather than profit growth. Versions of such communitarian organizations and associated labour forms have existed on the margins of industrial capitalism for a long time. But their recent increase could represent the historic emergence of enclaves of post-capitalist forms of organization and labour to ultimately take over capitalism as it finds it. One very promising example is the Organization Workshop initiated by Clodomir Santos de Morais in Latin America (Carmen and Sobrado, 2000) which, through the collective efforts of marginalized people, is now creating decent employment and sustainable communities in deprived areas in several countries. As capitalist production reaches its limits-- in terms of profitable commodification, ability to provide viable global employment and environmental degradation - growing numbers of marginalized people are very likely to turn to such alternative forms of production, including non-wage forms of labour. More generally, the notion of a social economy in which productive labour is motivated primarily by community sustainability has begun to take hold internationally.

The commodification of labours previously taken to be "natural" and therefore unpaid is also symptomatic of private capital's never-ending search for new sources of profit. In recent times we have witnessed increasingly extensive commodification of domestic labour. Private domestic cleaning and child care enterprises have emerged to provide profit-seeking services in this sphere for those households that can afford it. The feminist movement has sensitized women and men alike to the vital importance of unpaid housework and caring work for the reproduction of society, and more specifically to its comparable value. But the primary redistributive focus so far has been on pay equity in employment as women have increasingly entered competitive job markets. There has been little coordinated attention to the redistribution of domestic labour. Both the paid and unpaid divisions of domestic labour remain quite patriarchal. In spite of recent gains, women still get mainly poorer, more contingent jobs. Even more seriously, women are still doing the bulk of unpaid domestic labour and assume most of the responsibility. Younger men in dual-earner families are moving gradually to "helping her out". More significantly, neither men nor women have shown much inclination to delegate more intimate and personal aspects of domestic and childcare services to other, paid labourers. (The example of the strong negative reaction of kibbutz parents to limited access to their children under collective child care regimes is indicative.) As women employees' wages and bargaining power increase, there may well be an increasingly correspondent redistribution of unpaid domestic labour and child care between the sexes. But the continuing commodification of intimate personal services and child care may face inherent limits in capitalist societies with democratic polities. 
Similarly, with the growing atomization of communities in capitalist societies, the centrality of volunteer work in local social networks for ensuring sustainability of community life has also become more evident. The discovery of the productive value of "social capital" within localities and regions is closely related to this point. Commodification of community work has certainly occurred, including private recreation centers, fee paying public social service programs and paid instructors and coaches for various voluntary community organizations and clubs. But the bulk of community work remains voluntary, done with and for friends and neighbours on principles of mutual aid and without serious monetary compensation. The contradictions between private enterprise profitability and community sustainability generally incline the majority in most communities to do most community work for themselves.

In sum, conversion of more aspects of everyday production and consumption into saleable commodities continues, along with commercialization of further aspects of both domestic labour and previously voluntary community labours. But limits to indefinite further capitalist expansion are becoming evident in terms of long-term profitability declines, environmental degradation and various forms of global underemployment. Emergent alternative forms of productive labour are discernible both inside and on the margins of major employing organizations. In addition, many people are recognizing the social utility of their own housework and child care work and are beginning to renegotiate and effectively juggle domestic divisions of paid and unpaid labour rather than conceding the conversion of more intimate aspects of housework in to a profitseeking activity. Similarly, volunteer community work is frequently valued precisely because it is freely chosen in relation to our strongest interests and people are generally loathe to pay others to perform their most fulfilling activities.

As limits to expansion of capitalist production and associated wage labours become more apparent, we need to look more closely at the changing nature of paid and unpaid work in capitalist societies, their associations with different types of learning activities, and the significance of these learning an work relations for continuity and change in global capitalism.

\section{LEARNING AND WORK RELATIONS IN CAPITALIST SOCIETIES}

In capitalist societies, inter-firm competition, technological innovation, and conflicts between employers and employees over working conditions, benefits and knowledge requirements all lead to incessant shifts in the numbers and types of jobs available. Population growth cycles, modified household needs and new legislative regulations also frequently serve to alter the supply of labour. At the same time, popular demand for general education and specialized training increases cumulatively as people generally seek more knowledge, different skills and added credentials in order to live and work in such a changing society. In addition to these endogenous forces, external challenges-such as the Sept 11, 2001 "Attack on America" by anti-capitalist forces and the subsequent 
escalation to "preventative war" by Anglo-American forces-sometimes disrupt established supply-demand cycles of labour.

There are always some "mismatches" between employers' aggregate demand and requirements for employees on the one hand, and the aggregate supply and qualifications of job seekers on the other. The accelerating productivity of capitalist enterprises regularly throws workers into unemployment, reproducing the most evident part of a reserve army of labour. In societies like Canada with liberal democratic state regimes that acclaim the right to equal educational opportunity, and with labour markets in which both employers and job seekers make mainly individual employment choices, the dominant historical tendency has been for the supply of educationally qualified job seekers to exceed the demand for any given type of job. These same dynamics also generate formal underqualification of some workers, particularly older employees who are experienced and competent in their jobs but have had few incentives to upgrade their credentialed skills.

Careful assessments of the changing occupational composition of the employed labour force and of specific vocational preparation requirements for the aggregate array of jobs in countries like Canada and the U.S. have found that the knowledge workers often presumed to dominate in "knowledge-based economies" still comprise a small minority of the labour force, and that there has only been very gradual net upgrading of the actual skill requirements of jobs in general over the past few generations. In contrast, Canadian participation in post-secondary education grew about sixfold between the early 1960s and the late 1990s, with nearly half of the 20-64 population having attained a post-secondary credential by 1996. Adult course participation expanded even more rapidly, from 4 percent in 1960 to 35 percent in the early 1990s. In aggregate terms, formal educational qualifications now clearly exceed formal job entry requirements in many advanced industrial countries (see Livingstone, 2002, 2003).

Since formal education has increased rapidly while changes in skill requirements of the job structure have been more gradual, many people now find themselves underemployed in the sense that they are unable to use many of their employment-related skills in current jobs. As I have documented in detail elsewhere (Livingstone, 2002, 2003), there are at least six dimensions of underemployment: the talent use gap, structural unemployment, involuntary temporary employment, the credential gap, the performance gap and subjective underemployment. I will not elaborate on these dimensions here except to observe that recent survey estimates indicate that about 20 percent of the employed Canadian and U.S. labour forces now consider themselves to be subjectively underemployed, while around 30 percent have at least one credential higher than required for entry to their current job, and measures based on the general educational level required to perform the job suggest that as much as half of the labour force may have skill levels that exceed those actually required.

But an inclusive understanding of relations between learning and work in industrialized market societies requires careful consideration of the hidden dimensions or "underlayers". "Work" includes the aforementioned unpaid housework and community 
volunteer work, as well as paid employment. "Learning" includes informal training and non-taught learning, as well as organized formal schooling and further adult education.

In addition to our readily recognized formal education, we also continually engage in two sorts of informal learning activities to acquire understanding, knowledge or skill outside of the curricula of institutions providing educational programs, courses or workshops. Informal education or training occurs when mentors take responsibility for instructing others without sustained reference to a pre-established curriculum in more incidental or spontaneous situations, such as guiding them in learning job skills or in community development activities. All other forms of explicit or tacit learning in which we engage either individually or collectively without direct reliance on a teacher/mentor or an externally-organized curriculum can be termed non-taught self-directed or collective informal learning. As Allen Tough (1978) has observed, informal learning is the submerged part of the iceberg of adult learning activities. It is arguable that, for most adults, informal learning (including both informal training and non-taught learning activities) represents our most important learning for coping with our changing environment. No account of "lifelong learning" can be complete without considering peoples' informal learning activities as well as their initial formal schooling and further education through the life course.

The dominant focus on relations between paid employment and organized education ignores significant interactions between these and other dimensions of work and learning. However, researchers oriented to a presumed new era of "knowledge work" increasingly recognize that continued informal training and untaught learning are important for success in the context of paid workplaces. Recent survey studies have confirmed that most job-related training is done informally. Through a combination of initial schooling, further adult education, informal training and non-taught learning, the vast majority of workers manage to become at least adequately qualified for their current jobs. Yet the dominant discourse about a pressing need for creation of "learning organizations" largely ignores or depreciates these realities of interaction between organized education, informal training and untaught learning and job performance, and presumes that the central challenge for improved enterprise performance is for workers to become more active and motivated learners. Furthermore, many valuable transfers of knowledge and skill between these four basic forms of learning and among the three spheres of work are similarly unrecognized or discouraged by current workplace organization (see Livingstone, 2003).

We posit the extent of correspondence between knowledge attainments and work requirements to differ markedly by social position, with the greatest discrepancies experienced by those with the least economic or political power to define the appropriate requirements for their work. We expect to find highest levels of underutilization of working knowledge in the jobs held by those in lower occupational class positions, as well as among those job holders whose general subordination in society has put them at a disadvantage in negotiations over working conditions, especially women, younger people, ethnic and racial minorities, recent immigrants and those labelled as "disabled". Greater levels of correspondence should generally be found between unpaid work and informal learning because of less pronounced power hierarchies in these spheres of 
activity. But time devoted to unpaid domestic labour tends to be inversely related to economic and political power, with women who lack or have relatively little employment-based bargaining power still doing most of it with little recognition. The relative correspondence between different types of work and relevant informal learning activities should also vary according to how much discretionary control people can exercise over the work. Since people are not generally compelled to do community volunteer work, we can posit that relevant informal learning activities may be more closely associated with involvement in this sort of work than either hierarchically structured employment or necessary domestic labour. Empirical testing and further refinement of these posited learning and work relations are likely to provide a more effective guide to social policy making in the "new economy" of today than the simple assumptions of human capital theory or a knowledge-based economy perspective.

The research network on New Approaches to Lifelong Learning (NALL) ${ }^{\mathbf{i}}$ conducted the First Canadian Survey of Informal Learning Practices in 1998 with a representative sample of 1562 Canadian adults. Respondents were asked about their paid employment, housework, community volunteer work, as well as their schooling, further education and informal learning related to each sphere of work and other general interests. The survey design and basic findings have been reported in detail in other publications (Livingstone, 1999: Livingstone, 2002) and the NALL website: www.nall.ca.

According to NALL survey self-reports, around 95 percent of Canadian adults were devoting some time to intentional informal learning activities related to their paid employment, household duties, community volunteer work and other general interests, an average of about 15 hours a week, an apparent increase of about 50 percent since the first empirical studies were conducted in the 1960s. So intentional informal learning is much more extensive that adult education courses in which only around a third of all adults currently spend an average of only a few hours per week. In addition, the distribution of informal learning is quite equitable regardless of prior schooling. School dropouts and university graduates both spent an average of about 15 hours a week in informal learning. Adult informal learning is indeed like the submerged portion of an iceberg, not usually seen but essential to supporting the visible part.

Closer analyses of the interrelations between work and learning find that full-time workers are somewhat more likely than part-time workers to participate in further education courses but that the longer hours people are employed, the less time they tend to spend on job-related courses. However, there is generally a positive association between the amount of time that people spend in paid employment, household labours and community work and the time they spend in respective work-related informal learning. The association between community volunteer work and community-workrelated informal learning is much stronger $(\mathrm{r}=.48, \mathrm{p}<.001, \mathrm{~N}=760)$ than the relation between paid employment and job-related informal learning $(\mathrm{r}=.17, \mathrm{p}>.01, \mathrm{~N}=871)$. These findings confirm that the greater degree of discretionary control one has to engage in the particular sphere of work, the closer the relation between work time and informal learning time. The findings suggest that the most effective way to increase the 
correspondence between jobs and employment-related learning may be to increase job autonomy through workplace democratization.

As predicted, there are marked differences in underemployment rates between occupational classes. Only around 10 percent of corporate executives, professionals and managers have educational credentials greater than their jobs require for entry, while about 40 percent of service workers and industrial workers do. In spite of the general lack of access to university education for those from lower socio-economic statuses, there appears to be a massive underutilization of the achieved skills and knowledge of the working class in the current job structure.

But, regardless of the current mismatch between job skills and requirements, the vast majority of workers continue to be actively involved in quite extensive employmentrelated informal learning activities. Indeed, industrial workers are found to spend more time in employment-related informal learning (an average of 9 hours a week) than occupational classes with higher course participation rates, perhaps partly to compensate for limited access to organized courses. Recent time series research suggests there may be a substitution effect between course participation and informal learning, with informal learning increasing when course accessibility barriers increase (Livingstone, Hart and Davie, 2003). "Discouraged workers" and others outside the current "active" labour force also continue to be quite active informal learners in other spheres. Neither chronic unemployment nor other forms of underemployment have discouraged the pursuit of lifelong learning.

So, while there appear to have been only gradual changes in skill upgrading of the general job structure and incremental gains in the proportion of jobs predominantly involving the knowledge work of planning and design during the post-WWII period, rates of completion of post-compulsory schooling and participation in further education courses have grown exponentially. Employment-related informal learning is even more extensive and also apparently increasing. Rates of underemployment-in terms of structural unemployment, involuntary reduced employment and educational attainments exceeding job requirements- have also grown significantly during this period (Livingstone, 2003). Such evidence suggests that we already live in a learning society, but not yet in a knowledge-based economy.

\section{ECONOMIC REFORMS TO ADDRESS UNDEREMPLOYMENT}

This oversupply of qualified people for existing jobs continues to encourage employers to inflate required entry credentials as a means of selection. Indeed, credential underemployment may serve to stimulate still greater individual efforts to obtain further educational credentials and related skills to enhance relative chances in competitive job markets - a sort of educational arms race. The growth of knowledge is never a bad thing per se. But the underemployment of acquired knowledge and skills in current paid workplaces is becoming a very serious social problem. The reasonable solution to this problem is not to restrict access to educational institutions through higher fees or other 
means. This merely increases social inequities between those from affluent family origins and the rest of society (see Livingstone and Stowe, 2001). Besides, as the analysis of underemployment and learning activities shows, those who are underemployed would continue to seek further knowledge through informal means and their actual underemployment would persist. The only effective solutions to current underemployment problems are likely to be found in economic reforms that encourage increasingly highly educated labour force to make fuller use of their skills and knowledge in their workplaces.

As alluded to above, the three basic economic alternatives currently available to us are: shareholder capitalism; stakeholder capitalism and economic democracy. I have examined these economic alternatives and their basic learning and work links more fully elsewhere (see Livingstone 2003). Here I will only note that unless we have clear visions of the work alternatives that actually exist, that are preferable and that are feasible, we are unlikely to contribute to sustainable, progressive workplace change. My basic thesis is that greater genuine democratic participation will be associated with lower levels of underemployment.

The most feasible immediate work reforms include work redistribution and workplace democratization. In light of the increasing polarization of paid employment between those who feel compelled to work over 50 hours per week and those involuntarily working under 30 hours or unemployed, an obvious response is to redistribute employment hours among them. But even with significant paid work-time reduction measures, credential and performance-based conditions of underemployment are likely to persist among the employed labour force. If the performance-based measures of mismatch cited above are even remotely accurate, democratic workplace reorganization is greatly needed to allow many workers to use their skills and knowledge more fully in their jobs. There are multitudes of specific innovations (including work teams, job rotation, job enrichment, incentive pay, flexible scheduling, etc.) that have sometimes been successful in enhancing both the quality of working conditions and productivity per worker - when they are based on decent living standards, safe tasks in safe environments and open decision-making.

\section{CONCLUDING REMARKS}

Both survey data and more ethnographic studies (see Livingstone and Sawchuk, 2003) confirm that we are now living in an "information age" in terms of the accessibility of employment-related knowledge from multiple sources, and in a "learning society" in terms of the continuing learning efforts of most workers Although extensive underemployment contradicts the frequent claims that we are also living in a "knowledge-based economy", the lack of immediate opportunities to use their knowledge in available jobs has not dissuaded most workers from continuing to seek ever more of it. We now have a lifelong learning culture in the labour force but one which is insufficiently recognized in the design of many paid workplaces. Educational reforms should always be encouraged for human enrichment. But only economic reforms that 
address basic dimensions of work reform, including the redistribution of paid work time to reduce current polarization and the democratization of paid work to give more workers' greater opportunities to apply their extensive acquired knowledge, can substantially enhance the quality of employment. Without such major paid work reforms, the underemployment of most working people and their latent power to flourish in more democratic workplaces may continue to grow into the most serious political economic problem of the current century. It is now time for national-and international level forums which bring together all major interest groups in an open, informed debate about the most preferable, feasible economic alternatives to address underemployment, nurture development of a knowledge-based economy and continuing lifelong learning, and provide sustainable living conditions for all citizens. The excesses and limits of global capitalism require no less.

\section{REFERENCES}

Carmen, R. \& Sobrado, M. (2000). A Future for the Excluded. London: Zed Books.

Livingstone, D.W. (1999). Exploring the Icebergs of Adult Learning: Findings of the First Canadian Survey of Informal Learning Practices. Canadian Journal for the Study of Adult Education, 13(2), 49-72.

Livingstone, D.W. (2002). Working and Learning in the Information Age: A Profile of Canadians. Ottawa: Canadian Policy Research Networks. [www.cprn.org]

Livingstone, D. W. (2003). The Education-Jobs Gap: Underemployment or Economic Democracy. Toronto: Garamond Press.

Livingstone, D.W., Hart, D., \& Davie, L. (2003). Public Attitudes Toward Education in Ontario 1998: Fourteenth OISE/UT Survey. Toronto: OISE Press. [www.oise.utoronto.ca/OISE-Survey]

Livingstone, D.W. \& Sawchuk, P. (2003). Hidden Knowledge: Organized Labour in the Information Age. Toronto: Garamond Press, and Boulder: Rowman \& Littlefield.

Livingstone, D.W. \& Stowe, S. (2001). "Class and University Education: Intergenerational Patterns in Canada.” NALL Working Paper \#36. [www.nall.ca]

Tough, A. (1978). "Major Learning Efforts: Recent Research and Future Directions," Adult Education, 28, 250-263.

\section{ENDNOTE}

i *The Social Sciences and Humanities Research Council of Canada (SSHRC) provided funding to establish the NALL research network and conduct the first national survey of informal learning under SSHRC Grant Number 818-96-1033. Further information on this survey and other research activities of NALL may be found at the website: www.nall.ca. 